miration society in session, which adjourned only on the arrival of certain older members of my family. On nearly every pleasant day for the succeeding month we caught sight of him on one tree or another in the neighborhood, sometimes bearing a nut in his mouth, but oftener darting about as if simply enjoying himself among the variegated autumn leaves.

Our respect for this fellow-tenant of our grounds was greatly increased one day, when a neighbor, hearing us speak of him, told us how it came about that we enjoyed the pleasure of the little fellow's company. In this neighbor's yard stood a large tree on whose top was a stump left by a decayed and broken limb. One day it was determined to trim up this tree with some thoroughness. The workmen brought their ladder and began. Soon there appeared upon the scene a much disturbed gray squirrel. Excitement was evident in every movement as the trimming proceeded. Finally the workmen left their work for the day. When all had become quiet, my neighbor was privileged to see a curious sight-one which I cannot remember seeing or hearing described before. It was the removal of a squirrel family to a new home. The old squirrel seized each young one by the nape of the neck, while the little one threw its tail about the parent's neck, as if to hold on. Then the old one, with its precious freight, descended the tree to a boundary fence, and, by characteristic hops and runs, arrived at a hollow tree top between my house and my barn. Two or three such journeys were observed before the whole family was domiciled in the new quarters.

Whether this burden-bearer was the male or the female, I know not. Perhaps some reader of Science can tell me. Indeed, I do not know whether there are a pair of the old squirrels here or not. We have never been able to observe two together. It is plain that the old squirrel came to the conclusion that its young were unsafe in the former home. Was this an inference from observation of the falling branches? The mere presence of man could not have been the ground of the conclusion, for a group of boys had played about the tree all summer, and after the removal the squirrel's freedom. from fear in the neighborhood of human beings was often remarked. Its action in this instance resembles intelligence more than mere instinct.

Cambridge, Mass.

Ray Greene Huling.

\section{St. LOUIS LIMEstone in POWEShiek COUNTY, IOWA.}

The St. Louis limestone described by Hall and White, and more recently by Keyes (Geol. Ia. First Am. Rep., I892) was formerly known to occur only as far north as the eastern border of Mahaska County. Early in 1893 Bain traced this formation completely across the county in the beds of the Des Moines and South Skunk rivers, and in the North Skunk nearly to the northwestern corner. More recently several excellent exposures of this limestone have been discovered three miles above the southern line of Poweshiek County, thus extending its northern limit about ten miles beyond that previously reported. At one place nearly fifty feet of coal-measure strata were seen to rest upon the limestone. Generally, however, it was immediately overlaid with drift. Many fossils, in a fine state of preservation, were obtained from the marl which capped the rock.

Iowa College, Grinnell. Ia.
Arthur J. Jones.
Horsford's Acid Phosphate

Is the most effective and agreeable remedy in existence for preventing indigestion, and relieving those diseases arising from a disordered stomach.

\section{Dr. W. W. Gardner, Spring-}

field, Mass., says, "I value it as an excellent preventative of indigestion, and a pleasant acidulated drink when properly diluted with water, and sweetened."

Descriptive pamphlet free on application to Rumford Chemical Works, Providence, R. I. Beware of Substitutes and Imitations.

For sale by all Druggists.

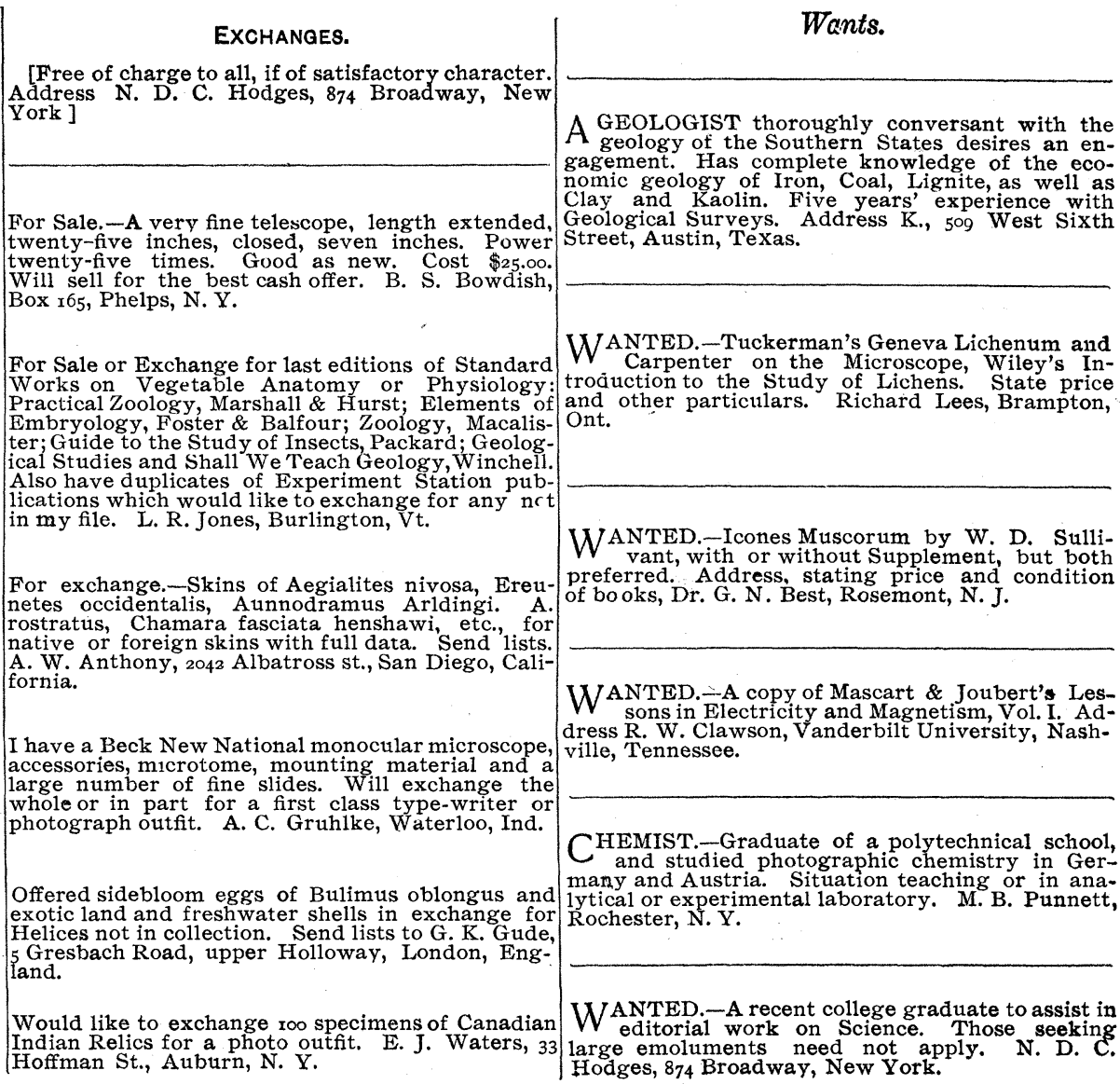

